\title{
Social Movements and Science: Cultural Appropriations of Cognitive Praxis
}

\author{
ANDREW JAMISON \\ Department of Development and Planning, Aalborg University, Denmark
}

The new millennium has brought with it increasingly shrill attacks on those of us who are concerned about the environment. Particularly in relation to such complicated and contentious issues as climate change, environmental scientists and activists have been subjected to criticism and even ridicule by a wide range of people, who have apparently grown tired of the costs of environmental protection. The American writer Michael Crichton, in his novel from 2004, State of Fear, brought these attacks into the cultural mainstream in a particularly outrageous fashion, as he depicted environmental scientists and activists as ruthless murderers and terrorists. Crichton refers in his book-for it is something so unusual as a novel with an annotated bibliography-to the importance for his understanding of environmentalism to the self-proclaimed environmental sceptic, Bjørn Lomborg, whose strange rise to fame and fortune has been chronicled in these pages (Jamison, 2004).

Like Lomborg, Crichton and the various lobbyists that have emerged in the wake of President Bush's refusal to accept the Kyoto agreements, make little attempt to disentangle what are rather complicated and not always friendly social relations between environmental scientists and environmental activists. It is all the same tribe to them, a mindless throng of believers-Crichton explicitly characterizes environmentalism as a religionwho do not practise what the critics call 'science'. One of the main bones of contention, in other words, is the understanding of what is meant by scientific knowledge, and what sorts of truths it actually provides.

It has been difficult for environmentalists to respond to the sceptics in an effective manner, since many, if not most, environmental scientists and activists continue to hold what might be termed a traditional view of science and of the social role of the scientist. Science is still seen by many environmentalists to provide an old-fashioned kind of 'objective knowledge' and, even though they must realize that environmental science has

Correspondence Address: Andrew Jamison, Department of Development and Planning, Fibigerstraede 13, Aalborg University, Aalborg, Denmark. Email: andy@plan.aau.dk 
somehow been shaped by environmental activism, those relations have seldom been examined explicitly. The sceptics' call for 'sound science' has thus tended to put environmental scientists and activists on the defensive.

The backlash or reaction to environmentalism that is such a visible feature of contemporary cultural life makes it important to consider, or reconsider, the relations between science and environmental movements, and, for that matter, science and social movements more generally. What is the role of social movements in the development of scientific knowledge? And is environmentalism a special case, or are there historical precedents and broader patterns that can help elucidate the contemporary debate?

\section{Social Movements as Cognitive Praxis}

The relations between social movements and science have tended to be neglected by academics and activists alike. In the academic world, this neglect has been largely due to specialization, by which students of social movements have come to be differentiated from those who are concerned with the interactions between science, technology and society. Social movements in general, and environmental movements in particular, tend to be studied either as delimited empirical phenomena mobilizing various kinds of political resources - this is the so-called resource mobilization, or political process theory of Sidney Tarrow and Charles Tilly, and most other North Americans; or as new social actors articulating one or another political ideology or collective identity-this is the so-called new social movements theory of Alain Touraine and Alberto Melucci, favoured by most Europeans [see Della Porta and Diani (1999) for an introduction to the field]. In both 'paradigms' and the numerous variants thereof, the relations between movements and scientific knowledge are seldom, if ever, examined explicitly.

Within the study of science, technology and society, or STS, on the other hand, social movements are a rather marginal area of interest; they are the stuff of an amorphous background to the main objects of investigation, namely scientists and their 'laboratory life', as the pioneering work in the field by Bruno Latour and Steve Woolgar so famously characterized the subject-matter of STS already in the late 1970s. It was then that the study of science, technology and society began to retreat from what might be termed the 'macro' level of society, where politics takes place, and focus more or less exclusively on the micro level of reality, where scientists and the various networks of actors that they are associated with are said to construct their 'facts' and theories.

Although there have been, in recent years, a number of attempts to consider the role of particular movements in relation to particular fields of scientific research, social movements remain marginal to the main orientations of science, technology and society studies. There have been those who have analyzed the role of patient movements in relation to particular areas of medical research, women's movements in relation to particular areas of social science and philosophy, and environmental movements in relation to particular aspects of environmental sciences. And it is, among other sources, these efforts which have contributed to the more general 'model' or theory that I will be presenting here.

What has been lacking is a more general conceptual framework for considering the relations between social movements and science, both in the contemporary world, as well as historically. Together with Ron Eyerman, I have attempted to fill this gap in understanding, by developing what we have characterized as a cognitive approach to the study 
of social movements, derived from critical theory, the sociology of knowledge and the theory of science and science studies (Eyerman and Jamison, 1991, 1998). Our approach grew out of research that we conducted with Jacqueline Cramer and Jeppe Læssøe on the history of environmental movements in Sweden, Denmark and the Netherlands (Jamison et al., 1990). In order to understand the relation between environmental movements and the development of knowledge, we invented the concept of 'cognitive praxis' to characterize the knowledge-making activity that takes place in social movements. The general idea is that the environmental movements that we investigated combined three different knowledge interests, which we characterized as cosmological, technological, and organizational. We then went on to claim that many other movements resemble the environmental movements we investigated by combining world-view assumptions (cosmology), criteria for technical change (technology), and organizational forms (organization) into an integrative cognitive praxis to provide an important part of what other movement theorists have termed 'collective identity'. We have never claimed that all movements have such an integrative cognitive praxis, nor have we meant to imply that cognitive praxis is all that goes on in movements; we have rather sought to accentuate and make explicit certain features of some movements, which are neglected by other theories.

In articulating the knowledge interests of the movements in which they participate, it is, we suggest, various types of 'movement intellectuals' who have often combined social roles and types of competence that were previously separated. And we suggest that such movement intellectuals have played a significant role throughout modern history, even though the movements in which they have participated have differed rather substantially. In relation to their cognitive praxis, there are intriguing similarities between, for example, the Protestant Reformation and some of the identifiable 'movements' that were active in sixteenth and seventeenth century Europe and the new social movements of recent decades. For all of their differences, one of the main features that they share is an interest in what might be termed hybridization, that is the bringing together of social roles and forms of knowledge that were previously separated for one reason or another (Hård and Jamison, 2005).

In the early modern period, the chemist Paracelsus and the astronomer Tycho Brahe were among the key individuals who brought the life-worlds of scholarship and craftsmanship together into a new 'hybrid identity'; and over the past two centuries, other movement intellectuals have served as initiators of key processes of hybridization out of which many scientific theories and practices have subsequently emerged. As such, it can be suggested that social movements and their intellectuals have periodically contributed to the construction of new scientific disciplines and institutions, as well as the formation of new identities and roles for scientists to play in society.

In what follows, I will discuss the interactions between social movements and science in broad, historical terms before delving into the relations between the "new social movements' of the 1960s and 1970s and changes in the contemporary scientific enterprise. The general aim is to show that social movements play an essential role in the creation of scientific knowledge. Through processes of cultural appropriation, ideas, techniques and organizational forms that have emerged in the cognitive praxis of social movements have become socially accepted forms of knowledge production. Appropriation can be thought of as taking place at different 'levels' that affect different fields of science in different ways. The more theoretical fields often appropriate ideas from the social movements at what might be termed a 'discursive' level, while in the more technical, or 
empirical fields of science appropriation is often more practical, or methodological. Organizationally, appropriation can be thought of as a kind of institutionalization process, by which the looser, more informal spaces that movements create for knowledge production are replaced, or taken over, by more established organizational forms. It is by attempting to unravel these multifarious processes of cultural appropriation that we might better appreciate the contribution of social movements to the development of scientific knowledge.

\section{Social Movements and the Making of Modern Science}

Already in his classic work from 1904, The Protestant Ethic and the Spirit of Capitalism, Max Weber suggested that the Protestant Reformation brought a new kind of human value system, or ethos, into European societies, which emphasized the importance of manual labour-and of technical improvements-in the expression of religious devotion. Knowledge became something that was to be made by humans, not revealed by God. As the Protestant ethic spread across Europe, working its way into different life-worlds and ways of life, it stimulated ever more 'scientific' approaches to the investigation of both human and non-human nature.

Within the social and religious movements of the sixteenth century, new kinds of intellectual activities emerged that combined philosophical ideas with technical interests. The mathematical logic of scholastic philosophers was combined with the practical skills of artisan craftsmen into a new kind of instrumental rationality. The previously separated roles, or identities of scholars and craftsmen were mixed together in new combinations, giving rise to what Edgar Zilsel (1941) termed the modern 'scientific spirit'. At the same time, a range of movement intellectuals propounded ideas about making knowledge useful by adopting new methods for investigating both human and non-human reality. As such, the cognitive praxis of the Reformation provided a point of departure for the discourses, methods and practices that would later come to be characterized as modern science.

In the course of the seventeenth century, these broader movements were gradually supplanted by the more formalized institutions of modern science (Figure 1).

It is possible to identify two different cycles of cognitive transformation in the making of modern science. The first was characterized by the primarily religious movements that were connected to the Protestant Reformation, while the second consisted of the more

\section{From movements... to institutions}

cosmology "protestant ethic" mechanical philosophy
technology instruments, experiments machines, methods

organization decentralized groups formal academies

Figure 1. The making of modern science 
explicitly political movements associated above all with the conflicts of the midseventeenth century during the English civil war. Both involved the societal, or cultural appropriation of the cognitive praxis of social movements (Hård and Jamison, 2005).

Even before Martin Luther nailed his theses on the church in Wittenberg in 1517, there was an identifiable social or cultural movement among humanist and religious reformers-devotio moderno - that represented a deep-seated challenge to traditional ways of thought, both in the scholarly and religious life-worlds (Mandrou, 1978). The British archbishop Thomas More (1478-1535), who coined the term utopia, and who battled with his king over the relations between church and state before he was beheaded, and the Dutch humanist Gerrit Gerritszoon, or Erasmus of Rotterdam (1466-1536), who was among the first to develop secular forms of scholarship, are probably the most famous 'movement intellectuals' from that time. But throughout Europe, in the period of the late Renaissance, there were a number of challenges to the established social and cognitive orders from both the learned and the landless, the noble and the poor. The Reformation itself was a mass movement of protest against the Roman Church and its imperial authority (which is why the members of the movement came to be called Protestants). It was a broad social and cultural movement that articulated and practised alternative, or oppositional, forms of cognitive praxis as part of its struggles.

Of especial importance for the making of modern science was the chemist and medical doctor Philippus Aureolus Theophrastus Bombastus von Hohenheim, better known as Paracelsus (1493-1541), who combined a questioning of established religious and political doctrines with an interest in observation, mathematics, mechanics and technical improvements. He developed an original chemical theory of his own, reforming the spiritual and mystical teachings of the alchemical tradition on the basis of his experiences as a healer and experimenter. His approach to medicine combined the philosophical and the practical, and the theories he developed sought to provide general principles for the treatment of disease, based on the observed activities of healers and alchemists of all kinds.

As would be the case with Francis Bacon in the seventeenth century, Paracelsus inspired a movement of followers in his name, the Paracelsians, who were especially active in the Lutheran regions of central Europe, encouraging educational and public health initiatives, as well as practising alchemical experimentation and the observation of natural phenomena. It was the Paracelsians, who were among the most active disseminators of the new ideas about the heavenly spheres and the human body that were formulated by the mathematician Nicolas Copernicus (1473-1543) and the anatomist Andreas Vesalius (15141564). Like the social movements of the more recent past, the Paracelsians provided a breeding ground for the cultivation of scientific ideas. As some of the movement's members won official recognition for their work, the broader links to social and educational reform - and to alchemical traditions-gave way to somewhat more professional forms of knowledge making.

Tycho Brahe was one of those who had been inspired by the Paracelsians, when he studied in Germany in his youth. On his return to his native Denmark, he was given the island of Hven in the Öresund to establish one of the world's first scientific communities (Christianson, 2000). For 20 years, from 1577 to 1597, Brahe carried out systematic observations of the heavenly bodies as well as chemical research, in order to 'test' the theories of Copernicus and Vesalius. Hven-or Venusia as Tycho Brahe called his scientific community-developed into a place where scholarship and craftsmanship were mixed into a combined set of practices. Brahe was perhaps the most visible figure in sixteenth century 
Europe to begin to fashion, in an explicit and coherent way, the modern scientific institution or social role. He rejected a professorial post at the university in Copenhagen and he neglected his 'traditional' responsibilities as a feudal lord in order to combine, as Zilsel (1941) put it, the previously separated roles of the craftsman and the scholar into what might be termed the hybrid identity of the modern scientist. At Hven, visitors could behold elaborate astronomical instruments, they could wander through gardens filled with exotic plants, laboratories designed for pharmaceutical experimentation, and they could even have a look at a printing press that was used for publishing the results.

In sketching the historical development of the role of the scientist in society, the sociologist Joseph Ben-David (1971) contrasted what he termed a 'scientistic movement' in the early seventeenth century with the institutionalization process of academy building and the actual formation of science that took place in the later seventeenth and early eighteenth centuries. But the making of modern science also drew on the experiences of the sixteenth century. Francis Bacon, the prophet of Ben-David's scientistic movement, was well aware of the practical utopia of Tycho Brahe when he articulated his enormously influential ideas about useful knowledge and his vision of the New Atlantis (Elzinga and Jamison, 1984). With Bacon, the making of modern science became programmatic, and in the period of civil war from 1640 to 1660, his writings inspired movements of Baconians, taking part in what Bacon had termed the 'great instauration'. Activist organizations, such as the Diggers of Gerrard Winstanley, carried out experiments in agriculture and medicine, and produced a vast amount of popular scientific and technical literature in their pamphlets and informal treatises (Webster, 1975).

Winstanley's ideal of knowledge, like that of Paracelsus in the sixteenth century, was eminently practical, but it was also moral and spiritual. To Bacon's notion of useful knowledge, Winstanley added what might be termed a sense of accountability, or social responsibility, as well as a deeper meaning for the pursuit of knowledge. Winstanley distinguished useful knowledge from the 'idle, lazy contemplation the Scholars would call Knowledg', which was 'no knowledg, but a shew of Knowledg, like a Parrat who speaks words, but he knows not what he saith' (Winstanley, 1973/1649, p. 126).

As the broader movements gave way to more established institutions, such as the Royal Society, the political and social experiments, and the idea of pursuing science for the good of the 'Common-wealth' came to be transformed into scientific experiments for the good of certain groups. This was a kind of counter-revolution. The open-ended movements of discovery and investigation came to be transformed into the institutions of modern science. Ingenuity was deflected into narrower trajectories, at the same time as the production of knowledge came to be supported by, and increasingly dependent on, the support of the powerful.

The new institutions of modern science did not go unchallenged. The experimental philosophy was opposed both by the upholders of traditional, religious knowledge, as well as by some of the older radicals and their descendants. In the later seventeenth and early eighteenth centuries, the scientific 'aristocracy' that had emerged in London and Paris at the Royal Society and the Académie des Sciences was challenged by new kinds of dissenting groups, as well as by representatives of the emerging middle classes. In this sense, the enlightenment was also a kind of social movement. Many of the radical dissenters fled from Europe to the colonies in North America, and some of them who stayed behind established scientific societies, often in provincial areas in opposition to the established science of the capital cities (Jacob, 1997). 
The new movements that developed in the Enlightenment and helped inspire the French-and American-revolutions objected to the limited ways in which the Royal Society and the Parisian Academy had organized the scientific spirit and institutionalized the new methods and theories of the experimental philosophy. The Enlightenment also led to a geographical diffusion of the scientific spirit to places like Scandinavia and North America, where academies of science were created in the eighteenth century. It also led to new kinds of scientific disciplines, and more generally to what Michel Foucault (1970) termed a new 'episteme' or cognitive regime: the naming, classifying and ordering of things, which is epitomized in the works of Carl von Linné, or Carolus Linnaeus (17071778), who was also an important actor in the establishment of the Swedish Academy of Sciences. The American Philosophical Society for the Promotion of Useful Knowledge, founded in Philadelphia in 1768, was a centre of scientific and technical activity in the colonies and, after the war of independence, it served as a base for the explorationand exploitation - of the North American continent. Under the leadership of Benjamin Franklin, it was a place where the particularly American form of 'republican' science was fostered.

The various attempts to democratize scientific education in the wake of the French Revolution and to apply the mechanical philosophy to social processes-i.e. to view society itself as a topic for scientific research and analysis-indicate how new forms of scientific knowledge making and new scientific institutions were once again the outcome of broader movements and their cognitive praxis. The revolutionary government was the first to establish a science-based institution of higher education, the École Polytechnique, and it was there that visions of a technocratic order developed in the writings of the count Saint Simon, and his secretary, August Comte. The institutionalization process included the articulation of new philosophies of sciencepositivism, in particular-and new disciplines, related to the needs of an industrializing social order: statistics, geology, thermodynamics, political economy, and the sociology of Comte.

As in the making of modern science, the so-called dialectics of enlightenment can be seen as a part of a cyclical pattern, a continuing process of movements and institutions in interaction (Figure 2).

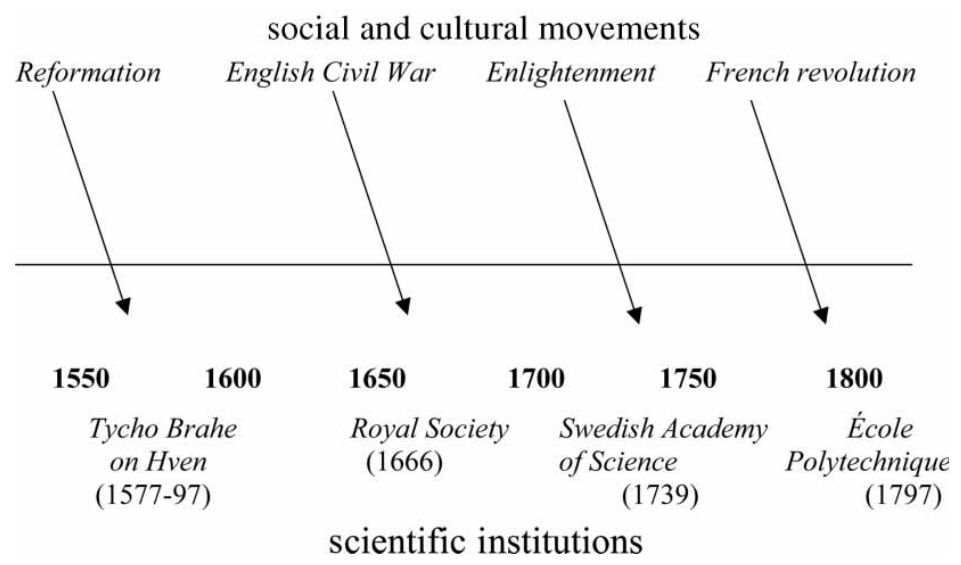

Figure 2. 


\section{Waves of Appropriation}

Similar cycles have characterized the interactions between social movements and science during the past two centuries. It can be helpful to think of them in relation to the long-term business cycles, or 'long waves' of industrialization that the economic historian Joseph Schumpeter delineated in his writings of the 1930s (Freeman and Louca, 2001). He drew on statistical investigations that had been conducted by the Russian economist Nicolai Kondratiev some years before, which had indicated that since the late eighteenth century, there had been three identifiable waves of industrial expansion and decline. The periods of expansion were characterized by rising rates of productivity and employment in the leading industrial countries, and roughly corresponded to the so-called boom periods of the original 'industrial revolution' of 1780-1810 and the continental expansion of 1845-1870. Schumpeter also identified a third period of expansion, from 1890 to 1915 that had followed the downturn and recession of the $1870 \mathrm{~s}$ and $1880 \mathrm{~s}$.

In his book, Capitalism, Socialism and Democracy, which he published in 1942, Schumpeter used the term 'creative destruction' to indicate that each wave had not merely replaced the previous one, but that it had also eliminated or destroyed much of the material basis of the preceding period. By mobilizing radical innovations that had brought with them a range of new technical opportunities into the productive spherethe textile machines in the first wave, the railroads and telegraph in the second, electricity and organic chemistry in the third-entrepreneurs and engineers had been able to create new branches of industry, as well as fundamentally different types of products in each of the waves. The first wave had been a wave of mechanization, the second of transportation and communication, and the third of electrification and 'chemicalization'. As such they had built on each other, but the actual goods and services that were produced, and the types of actors and institutions involved in their production, had been creatively destroyed or transformed from one wave to the next.

In regard to social movements, it is interesting to note that the periods 'in between' the waves, the periods marked by economic stagnation and decline, were also periods characterized by rather intense cultural and social protest activity. In the 1810s and 1820 s, as well as in the 1860 s and 1870 s, there emerged both movements of resistance and opposition, as well as influential intellectual responses to technological development, identifying problems but also pointing to new solutions. In the first period, there was both the emergence of romanticism among writers and artists and positivism among scientists and engineers, and, in many countries, cooperative movements developed among craftsmen and farmers. In the second period, socialist and populist ideas and movements helped give meaning to the ensuing developments in technology and science, and labour, or working-class movements emerged throughout the world with their own forms of cognitive praxis and their own movement intellectuals-such as Karl Marx, Mikhail Bakunin, and Henry George. Similarly, in the 1910s and 1920s, and then again in the 1960s and 1970s, there were widespread public debates, and a range of new actors and movements emerged-fascist, communist and national liberation movements in the earlier period, and the new social movements of antiimperialism, environmentalism, and women's liberation in the latter. To a large extent, these phases of social movements can be seen as cultural responses to the long waves of industrialization (Figure 3). 


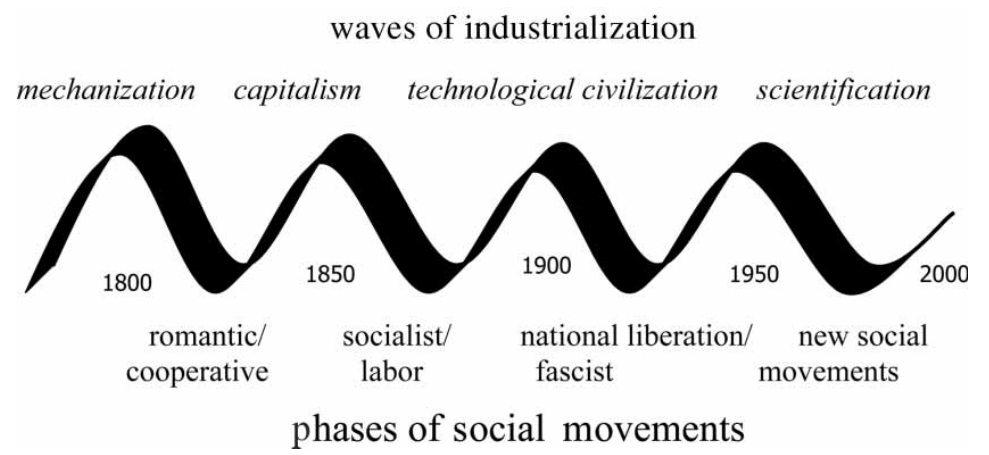

Figure 3.

By responding to one wave of industrialization, cultural and social movements have helped to constitute the next. In each of the waves, there have been characteristic processes of cultural appropriation, as the cognitive praxis of movements has gradually been transformed into scientific discourses, institutions and practices. Romanticism first emerged as a wide-ranging cultural critique of the hubris of science in the guise, for example, of Mary Shelley's mad Doctor Frankenstein. Romantic writers and artists were critical of the reductionism and cultural blindness of science and what William Blake called the 'dark satanic mills' in which the mechanical worldview was being applied. They sought to mobilize the senses in order to envision and create other ways of making knowledge (Roszak, 1973). Cooperation, in the form promulgated by the factory owner Robert Owen, was a reaction, among other things, to the problematic ways in which the technological applications of scientific activity were being spread into modern societies. Its cognitive praxis included, on a cosmological level, the socialist and egalitarian ideas of Owen and William Thompson in Britain and of Charles Fourier and Etienne Cabet in France, as well as the practical experiments that took place in the socalled utopian communities that Owenites and others established in North America. The writings of the Danish priest Frederic Grundtvig, with his critique of the 'Latin learning' at the universities, were important for the eventual formation of people's high schools in the countryside, where populist approaches to science could develop. Throughout the industrializing world, the romantic revolt inspired both the first flowerings of environmental concern in the form of conservation societies and institutions, as well as new kinds of holistic, or non-reductionist sciences, such as geography, archaeology and ecology.

In the late nineteenth century, the labour movement also sought a deep-going, fundamental transformation of society, but it would see its critical message translated, in the twentieth century, into packages of reforms and a more welfare-oriented capitalism, on the one hand, and into the 'scientific socialism' of Lenin and Stalin on the other. Once again, however, science benefited from this institutionalization of the cognitive praxis of social movements; the knowledge interests of the labour movement entered into the new social science disciplines of economics and sociology, and the institutions of social work, urban and regional planning. What began as a social movement challenge was once again transformed into scientific discourses, methods and practices; but while new forms of science and scientific expertise were developed, little remained of the broader 
knowledge making ambitions that the labour movement, in its more radical days, had articulated and practised.

In the early twentieth century, the challenge to established science was mobilized most actively in the colonies of European imperialism, as well as in the defeated imperialist powers of Germany and Italy; the critique was primarily of technological civilization writ large. In the name of modernity, science stood for the future and legitimated, in the colonies as well as in Europe and North America, a wholesale destruction of the past and of the traditional knowledges that had been developed in other civilizations. These social movements had an impact on politics on both the right and left, and as their cognitive praxis was appropriated, more explicitly proletarian and fascist sciences were created. While the movements of anti-colonialism inspired new sciences of ethnography and anthropology, and bring about mixtures of traditional knowledge and modern science in the writings of such movement intellectuals as Mahatma Gandhi and Ramachandra Tagore in India, fascism encouraged the development of race sciences and eugenics, while communism turned Marxism into a 'science'. The experiences of the interwar years thus make it clear that the relations between social movements and science are by no means inevitably progressive.

\section{Science and Contemporary Social Movements}

In recent decades, social movements have also served to challenge and reorient the scientific enterprise. Out of the anti-imperialist and student movements of the 1960s and the environmental and women's liberation movements of the 1970s have emerged a range of alternative ideas about science, in form, content, and meaning, which have given rise to new theories, academic fields, and technological developments. What in the $1960 \mathrm{~s}$ and 1970s were oppositional social movements have largely been emptied of their radical content, at the same time as they have given rise to new branches of, and approaches to, science and technology. While the more radical, or oppositional, voices have lost much of their influence, the more pragmatic and realistic voices have been given a range of new opportunities.

The new social movements rose to prominence in the downturn of a period of industrial expansion and economic growth. They emerged in opposition to the dominant social order and to its hegemonic cognitive regime, which had been largely established during and immediately after World War II. The war led to a fundamental transformation in the relations between science and politics and to a new, more intimate connection between science and economic production. Unlike previous phases of industrialization, in which science and engineering had lived parallel but separate identities, World War II ushered in the era of 'technoscience' (Elzinga and Jamison, 1995).

Especially important for the movements that emerged in the 1960s and 1970s was the crucial role of scientific research in postwar economic development. Many of the economically significant new products, such as synthetic textiles, plastics, portable radios and television, were based directly on scientific research; it was the era of chemical fertilizers and insecticides, of petrochemical-based process industries, and food additives. The forms of science also differed from the ways in which science had been organized in the past. The big science laboratories-both in the public and private sectors-were like industrial factories, and scientific-technical innovation came to be seen as an important concern for business managers and industrial organizers. The use of science in society 
had become systematized, and, as the consequences of the new order became more visible, new forms of criticism and protest developed (Jamison, 2001).

One wing of the public reacted to the destruction of the natural environment, what an early postwar writer, Fairfield Osborn, termed 'man's war with nature'. The exploitation of natural resources was increasing and, in the 1940s and 1950s, it began to be recognized that the new science-based products were more dangerous for the natural environment than those that had come before. But it would only be with Rachel Carson, and her book Silent Spring in 1962, that an environmental movement began to find its voice and its characteristic style of expression (Jamison and Eyerman, 1994). It was by critically evaluating specific instances of scientific technology, particular cases of what Osborn had called the 'flattery of science', that the environmentalist critique would reach a broader public. Carson singled out the chemical insecticides for detailed scrutiny and assessment, but her point was more general. Carson's achievement was to direct the methods of science against science itself, but also to point to another way of doing things, the biological or ecological way-what she called in her book the road not taken.

Another source of inspiration for the new social movements came from philosophers and historians who questioned the more general impact of technoscience on the human spirit. It was one-dimensional thinking which critical theorists like Herbert Marcuse (1964) reacted against, the dominance of an instrumental rationality over all other forms of knowing. For Lewis Mumford (1970), another major source of inspiration, it was the homogenization of the landscape that was most serious, the destruction of the organic rhythms and flows of life that had followed in the wake of postwar economic growth, as well as the dominance of what he termed the 'megamachine', the use of technology for authoritarian and primarily military purposes.

In the 1970s, a range of new social movements, building on these and other sources of inspiration, came to practise utopian or alternative approaches to science and technology (Dickson, 1974). The intellectuals of the new social movements articulated a set of knowledge interests, which combined the environmental critique of Rachel Carson and Fairfield Osborn with the liberation dialectics of Marcuse and the spirit of opposition that was mobilized against the war in Vietnam. The new movements involved a fundamental critique of modern science's exploitative attitude to nature and its subservience to the 'military-industrial complex', as well as an alternative organizational ideal-a democratic, or participatory ideal-for the making of knowledge. There were also distinct forms of collective learning in the new social movements of environmentalism and feminism, as well as grass-roots engineering activities that went under the name of appropriate or alternative technology.

New kinds of feminist theories were propagated both in the humanities and the social sciences, and, in the 1970s, female scientists and engineers began to explore the gender aspects of the natural and engineering sciences as well. Women's studies departments represented an important addition to many US universities, even though they were slower to emerge in Europe and the rest of the world. And beyond women's studies itself, feminism or gender theories provided an important new dimension to the broader political discussions of science and technology in society.

The women's movement opened up new themes and topics for investigation, and helped change research priorities and agendas across the entire realm of technoscience. In many technological universities, female scientists and engineers developed research programmes on technologies of everyday life, as well as on the relations between women 
and technology. In particular, reproductive technologies and issues related to genetic testing became an area where feminist scholars made seminal contributions. On a more theoretical or conceptual level, feminist theorists, such as Evelyn Fox Keller, helped direct attention to the metaphors and, more generally, the linguistic conventions of science, especially in genetics (Keller, 1985). The writings of Sandra Harding and Donna Haraway have exerted a strong influence on the philosophy of science, and helped bring about an awareness among philosophers to gender issues (Harding, 1998). Haraway has been particularly important in conceptualizing hybrid forms of reality, or what she has famously termed cyborgs, and for developing approaches to philosophy that attempt to break the old dichotomies between subject and object, the personal and the social, and, not least, the human and the non-human (Haraway, 1991).

\section{From Cognitive Praxis to Science}

On the basis of these historical and contemporary experiences, it can be concluded that social movements serve as crucial 'sites' for the constitution and reconstitution of the scientific enterprise. The new public spaces, or arenas that are carved out by social movements often provide the setting for innovative forms of cognitive praxis, combining new worldview or cosmological assumptions with alternative organizational forms and technological criteria. In the case of environmentalism, the cosmology was, to a large extent, the translation of a set of scientific concepts into a socioeconomic paradigm (Cotgrove, 1982). In the 1970s, the holistic ideas of systems ecology were transformed into political programmes of social ecology, and an ecological worldview was proposed by movement intellectuals, such as Barry Commoner and E. F. Schumacher, to govern social and political relations, and to help manage the relations between humans and their natural surroundings. Technology was to be developed under the general perspective that 'small is beautiful' [in the influential phrase of E. F. Schumacher (1973), 'as if people mattered'], and according to the assumption that large-scale, environmentally destructive projects should be opposed and stopped. At the same time, new contexts for education and experimentation and for the diffusion of scientific knowledge were created in the form of movement workshops and public information campaigns, especially in relation to energy production and use. In the Netherlands and later throughout Europe there developed 'science shops' where activists could gain access to scientific expertise at the universities, and, in many environmental groups, a kind of 'citizen science' was carried out in assessing the environmental and social consequences of particular manifestations of science-based production (Irwin, 1995).

In the course of the 1980s, this cognitive praxis was more or less decomposed, or deconstructed, into a cluster of organizations and individuals, through processes of professionalization and specialization (Jamison, 2001). The knowledge interests of the environmental movement were transformed into various kinds of professional expertise, which made it possible to incorporate parts of the movement into the established political culture, and to shift at least some of the members of the movement from outsider to insider status. Some of the alternative technical projects proved commercially viable-ecological agriculture, wind energy, waste recycling - and gave rise to a more institutionalized form of environmental politics, science, and technology.

The disparate array of environmental sciences that have now become institutionalized both at universities as well as at other sites in both the public and private sectors can be 
seen to be a direct outgrowth of the environmental movements of the 1960s and 1970s. But the processes of cultural appropriation have been contentious, and filled with ambiguities and tensions. On the one hand, there has been a dominant strategy, or cognitive regime of commercialization, what I have termed green business. As has been the case in many other areas of technoscience, such as genetic engineering and nanotechnology, there has developed a new 'mode' of scientific knowledge production within the environmental field, organized primarily in ad hoc projects that are oriented to contexts of commercial application (Gibbons et al., 1994).

On the other hand, many environmental scientists have returned to the established scientific disciplines and developed specialty areas within larger fields: environmental economics, environmental chemistry, environmental history, geography, oceanography, earth sciences, etc. The traditional disciplines have served in this way as a kind of residual cultural formation, to borrow a concept from Raymond Williams (1977). They have provided the basis for a cognitive regime by which environmental science or green knowledge making is subordinated to other discursive or interpretative frameworks.

In between, there is a third, ideal-typical approach to environmental science that seeks to keep open the spaces, or contexts of mediation where activists and academics can meet and form 'hybrid identities' that transcend disciplinary boundaries without necessarily being captured by the dominant or residual regimes (Jamison, 2005). As cognitive praxis, the environmental sciences are a field of contentious politics, where these different strategies of appropriation vie for economic and cultural resources, as they develop their theories and methods of research.

Similar processes can be identified in relation to other social movements of recent decades, especially the movements of women's liberation (Rose, 1994). The political struggles for civil rights, women's and sexual liberation, and ethnic and national identity have inspired new approaches to knowledge that have since been institutionalized and transformed into established scientific fields. But they have also given rise to emerging fields such as women's and gender studies, African-American studies, postcolonial and cultural studies, as well as new branches of medicine and engineering, such as technology assessment, bioethics, and social pharmacy.

At the same time, science itself has been reconstituted, partly as a result of the cognitive perspectives and challenges posed by social movements. Many of the so-called "postmodern' theories of the cultural and human sciences have been inspired by the new social movements. Out of the alternative public spaces that have been created by social and political movements has emerged a new kind of scientific pluralism, or multiculturalism, in terms of organization, world-view assumptions, and technical application.

In the 1970s, the view of a unified or universal science, based primarily on physics, which had dominated the theory of knowledge since the nineteenth century gradually began to be supplanted by what might be termed cognitive differentiation, and, as a result, Science with a capital letter has tended to become, for many practitioners and non-practitioners alike, a multiplicity of sciences. Throughout the world, the hegemony of the natural sciences and the 'leading role' of physics have been challenged by the emergence of new fields within the natural, social and human sciences, as well as within medicine and engineering. Even more importantly the dominant perception of Western science as the only legitimate form of knowledge production has been questioned by various 'ethnosciences' from other parts of the world, as well as by ethnic minorities within the industrialized, Western world itself (Jamison, 2000). 
In the transformations of movements into institutions, a significant channel of cognitive and cultural change can thus be identified. Of course, the processes of cultural appropriation have differed through the centuries. Both the substantive nature of the movements, as well as the substantive theories and practices of the ensuing sciences have differed in fundamental ways from the early modern period to our own times. And yet, the form of interaction has displayed certain underlying continuities. What seems to be central to scientific knowledge is its collective origin, or, at least, its basis in some kind of collective knowledge interests. What has recurred through history has been both an institutional narrowing, or closing, of what have often been broader and more open forms of knowledge production, as well as an individualizing of what often began as processes of collective creativity. It might be suggested that by focusing their attention as much as they have on individuals, historians and other students of science have thus tended to neglect the collective basis of much, if not all, scientific knowledge. It may be hoped, in conclusion, that these interactions between social movements and science will receive more sustained attention from both academics and activists in the years to come.

\section{References}

Ben-David, J. (1971) The Scientist's Role in Society: A Comparative Study (Englewood Cliffs: Prentice-Hall).

Christianson, J. (2000) On Tycho's Island. Tycho Brahe, Science and Culture in the Sixteenth Century (Cambridge: Cambridge University Press).

Cotgrove, S. (1982) Catastrophe or Cornucopia: The Environment, Politics and the Future (Chichester: John Wiley).

Della Porta, D. and Diani, M. (1999) Social Movements. An Introduction (Oxford: Blackwell).

Dickson, D. (1974) Alternative Technology and the Politics of Technical Change (London: Fontana).

Elzinga, A. and Jamison, A. (1984) Making dreams come true: on the role of practical utopias in science, in: E. Mendelsohn and H. Nowotny (Eds) Nineteen Eighty-Four: Science between Utopia and Dystopia (Dordrecht: Reidel).

Elzinga, A. and Jamison, A. (1995) Changing policy agendas in science and technology, in: S. Jasanoff et al. (Eds) Handbook of Science and Technology Studies (London: Sage).

Eyerman, R. and Jamison, A. (1991) Social Movements. A Cognitive Approach (University Park, PA: Penn State University Press).

Eyerman, R. and Jamison, A. (1998) Music and Social Movements (Cambridge: Cambridge University Press). Foucault, M. (1970) The Order of Things. An Archeology of the Human Sciences (New York: Random House).

Freeman, C. and Louca, F. (2001) As Time Goes By. From the Industrial Revolutions to the Information Revolution (Oxford: Oxford University Press).

Gibbons, M. et al. (1994) The New Production of Knowledge (London: Sage).

Haraway, D. (1991) Simians, Cyborgs, and Women: The Reinvention of Nature (New York: Routledge).

Hård, M. and Jamison, A. (2005) Hubris and Hybrids. A Cultural History of Technology and Science (New York: Routledge).

Harding, S. (1998) Is Science Multicultural? Postcolonialisms, Feminisms, and Epistemologies (Bloomington, IN: Indiana University Press).

Irwin, A. (1995) Citizen Science. A Study of People, Expertise and Sustainable Development (London: Routledge).

Jacob, M. (1997) Scientific Culture and the Making of the Industrial West (New York: Oxford University Press). Jamison, A. (2000) Globalization and the revival of traditional knowledge, in: J. Schmidt and J. Hersh (Eds) Globalization and Social Change (London: Routledge).

Jamison, A. (2001) The Making of Green Knowledge. Environmental Politics and Cultural Transformation (Cambridge: Cambridge University Press).

Jamison, A. (2004) Learning from Lomborg: or where do anti-environmentalists come from?, Science as Culture, 13(2). Jamison, A. (2005) Hybrid identities in the European quest for sustainable development, in: R. Paehlke and D. Torgerson (Eds) Managing Leviathan (Peterborough, Canada: Broadview Press). 
Jamison, A. and Eyerman, R. (1994) Seeds of the Sixties (Berkeley, CA: University of California Press).

Jamison, A., Eyerman, R., Cramer, J. and Læssøe, J. (1990) The Making of the New Environmental Consciousness. A Comparative Study of the Environmental Movements in Sweden, Denmark, and the Netherlands (Edinburgh: Edinburgh University Press).

Keller, E. F. (1985) Reflections on Science and Gender (New Haven: Yale University Press).

Mandrou, R. (1978) From Humanism to Science 1480-1700 (Harmondsworth, UK: Penguin Books).

Marcuse, H. (1964) One-Dimensional Man (Boston: Beacon Press).

Mumford, L. (1970) The Pentagon of Power (New York: Harcourt Brace Jovanovich).

Rose, H. (1994) Love, Power and Knowledge. Toward a Feminist Transformation of the Sciences (Cambridge, UK: Polity Press).

Roszak, T. (1973) Where the Wasteland Ends: Politics and Transcendence in Post-industrial Society (New York: Anchor).

Schumacher, E. F. (1973) Small is Beautiful: Economics as if People Mattered (London: Blond and Briggs).

Webster, C. (1975) The Great Instauration. Science, Medicine and Reform 1626-1660 (New York: Holmes and Meier).

Williams, R. (1977) Marxism and Literature (Oxford: Oxford University Press).

Winstanley, G. (1973/1649) The Law of Freedom and Other Writings (Harmondsworth: Penguin).

Zilsel, E. (1941) The sociological roots of science, American Journal of Sociology, 47. 
